\title{
Does the Domestication of Yam Wild Type Dioscorea praehensilis and Dioscorea abyssinica has a Genetic Basis?
}

\section{Gustave DJEDATIN1 , Kifouli ADEOTI2, Ebenezer EWEDJE³, Clement AGBANGLA ${ }^{4}$}

\begin{abstract}
${ }^{1}$ Laboratoire de Biologie moléculaire et de Bioinformatique Appliquée à la génomique (BIOGENOM); Faculté des Sciences et Techniques de Dassa-Zoumé, Université Nationale des Sciences, Technologies, Ingénierie et Mathématiques (UNSTIM), Bénin

${ }^{2}$ LAMITA, Faculté des Sciences et Techniques, Département de Biologie végétale, Université d'Abomey-Calavi (UAC), Bénin

${ }^{3}$ Laboratoire de Biologie, Ecologie végétale appliquée et de génétique forestière; Faculté des Sciences et Techniques de Dassa-Zoumé, Université Nationale des Sciences, Technologies, Ingénierie et Mathématiques (UNSTIM), Bénin

${ }^{4}$ Laboratoire de Génétique et des Biotechnologies, Faculté des Sciences et Techniques (FAST), Université d'Abomey-Calavi (UAC), Bénin
\end{abstract}

\begin{abstract}
Guinea yam (Dioscorea cayenensis-D. rotundata complex) is prone to strong genetic erosion. The main causes are climate change, depletion of the soil, the evolution of cultural practices, etc. To combat this threat, several alternatives are possible including domestication process. Indeed, domestication is an ancestral knowledge which is the introduction of wild yams' tubers to the field. The choice of genotypes to be domesticated is made on the basis of morphological criteria by farmers. To better understand this process and in order to know if it has a genetic basis, survey and sampling were done, in eleven forests and savannas, using a participatory approach strongly involved current and former yam domestication practicing. Based on farmers' criterions, 140 tubers belonging to $D$. praehensilis and $D$. abyssinica were sampled including 53 domesticable $D$. abyssinica, 38 non domesticable $D$. abyssinica, 19 domesticable $D$. praehensilis and 18 non domesticable $D$. praehensilis and 12 controls $(D$. togoensis and $D$. bulbifera). The morphological characterization using the IPGRI descriptors displayed differentiation between domesticable and non-domesticable $D$. praehensilis with few misclassified samples while a continuum was observed between domesticable and non-domesticable $D$ abyssinica. Nuclear microsatellites markers revealed a fine genetic structuring of these two wild species. Indeed, a clear separation of each of the two species D. abyssinica and $D$. praehensilis in domesticable and non-domesticable was detected. This supports the hypothesis of the existence of a strong genetic component in the ability to domesticate yams. These molecular data were congruent with the knowledge of farmers separating $D$. abyssinica and $D$. praehensilis into domesticable and non domesticable groups on the basis of morphological characters.
\end{abstract}

Keyswords: Dioscorea abyssinica, Dioscorea praehensilis, Domestication, Genetic Basis, Microsatellites Markers

\section{INTRODUCTION}

Yam (Dioscerea spp.) plays an important role in the human diet because of its wealth in starch, carbohydrates, proteins, vitamins and minerals (Megh et al. 2003; Adejumo et al, 2013). It is eaten boiled, fried, grilled, or crushed. It is an important food crop in most of west Africa countries. Yam is widely grown in West Africa, from Ivory Coast to Cameroon which represents the largest area of production in the world with $95 \%$ of the world production estimated to 60.530.000 tons in 2013 (FAOSTAT Database,
2014). Benin is the fourth world yam producer behind Nigeria, Ivory Coast and Ghana (FAO 2014). In Benin, yam' production has strongly increased in recent years. Nearly half of the Beninese population uses it as staple food. The marketing of some derived products such as yam' chips increases its market value (Vernier et al., 1998). Apart from its uses as a staple food, yam is also used for other purposes. In many regions of Benin and even in other African countries, some varieties of yams are used during traditional ceremonies either for wedding ceremonies or offerings to the ancestors or to protect fields

This article is published under the terms of the Creative Commons Attribution License 4.0

Author(s) retain the copyright of this article. Publication rights with Alkhaer Publications.

Published at: http://www.ijsciences.com/pub/issue/2017-11/

DOI: 10.18483/ijSci.1431; Online ISSN: 2305-3925; Print ISSN: 2410-4477 
against evil spirits (Orkwor et al., 1998; Baco, 2000; Okry, 2000). There are also wild yams with pharmaceutical interest (Malaurie et al., 1997). Several varieties are cultivated and their choice is dictated by a certain number of farmer' criteria such as the organoleptic quality, performance and adaptability to the growing environments (Dang, 1999).

Currently, this plant is prone to strong genetic erosion through the disappearance of several varities (Dansi et al., 1997). The main causes are climate change, depletion of the soil, the evolution of cultural practices, etc.

To combat this genetic erosion, several alternatives are possible: conservation (research station, in vitro and in situ) and varietal improvement by sexual reproduction and domestication. Conservation using research station is too expensive and annual losses due to many factors reach $47 \%$ (Dang et al., 1998). However, in vitro conservation is static, limited and requires significant financial resources (Doukouré, 2000). In situ conservation is complex and little functional. Due to the absence or the difficulties of flowering and fruiting, as well as polyploid yam nature, plant breeding sexually is often long, tedious and inappropriate for all varieties. It is actually considered to be a source of variability little exploited (Akoroda, 1983). The most appropriate way for yam breeding remains domestication. In fact, most of the varieties cultivated derived from domestication of wild species such as Dioscorea praehensilis and Dioscorea abyssinica. Domestication is an ancestral knowledge which is the introduction of wild yams' tubers to the field (Dumont, 1998; Baco, 2000; Okry, 2000; Dumont and Vernier, 2000). But this knowledge is very little developed due to many reasons. Wild yam domestication is controlled by a small number of farmers. The choice of genotypes to be domesticated is made on the basis of morphological criteria described by Dumont (1998). Moreover, taking into account the different production areas and ethnic groups from Benin, 4\%, 9.2 and $19 \%$ respectively of the bariba, nago and fon, control this method (Baco, 2000; 0kry, 2000; Tostain et al., 2002). Through, bariba' ethnic group area, wild yam domestication is considered as a shameful act. Another important aspect is rampant deforestation (ca. 60000 hectares of forest lost each year) that threatens the habitat of wild yam used for domestication which represents an important resource to combat genetic erosion (FAO, 1999).

Wild yam domestication is in decline in Benin and it is important to understand and document this practice. Thus, the overall objective of these studies is to investigate farmers' criteria and understand the genetic basis which support these criteria. To achieve this goal, three specific objectives were defined: 1) establish a collection of wild domesticable and nondomesticable yams from a wide participatory exploration in different forests and savannas of Benin; 2) make a morphological characterization of domesticable and non domesticable genotypes collected using International Bioversity (ex IPGRI) descriptors ; and 3) study the genetic diversity of this collection using nuclear microsatellite markers.

The results can let know whether wild yams in domesticable and non-domesticable distinction criteria used by Beninese farmers have a genetic basis.

\section{MATERIALS AND METHODS}

\section{Area of study}

The study areas were chosen taking into account the geographical distribution of the two wild yams species in Benin (Dang, 1997). Indeed, the North is the natural range of Dioscorea abyssinica, whereas D. praehensilis is mostly represented in the South. These two species are sympatric in the Center. Survey and sampling were done using a participatory approach. Current and former yam domestication practicing were strongly involved in the survey as well as in the sampling. They were subjected to an investigation followed by questioner about their experience in domestication practices, the nature of the wild material to domesticate, sampling sites and the criteria for selection of material to be domesticated. Collection sites are summarized on Figure 1. They were close to or located into the protected areas of Benin described below:

-The forest of Ouenou/Benou (located near the villages Pedarou and Fôbouré), the forest of three rivers (areas of Zougou-Pantrossi and Dougoulaye), in the North;

-The forest of Toui-Kilibo (in the zone of Papane and Toui) in the Center;

-The forest of Lama (in the village Koto), the forest of Ewe, the island forests of Sozoun and Hizihan, the gallery forests of Bozoundji and Lanwlixa, all in the locality of Ketou in the Southern Benin 

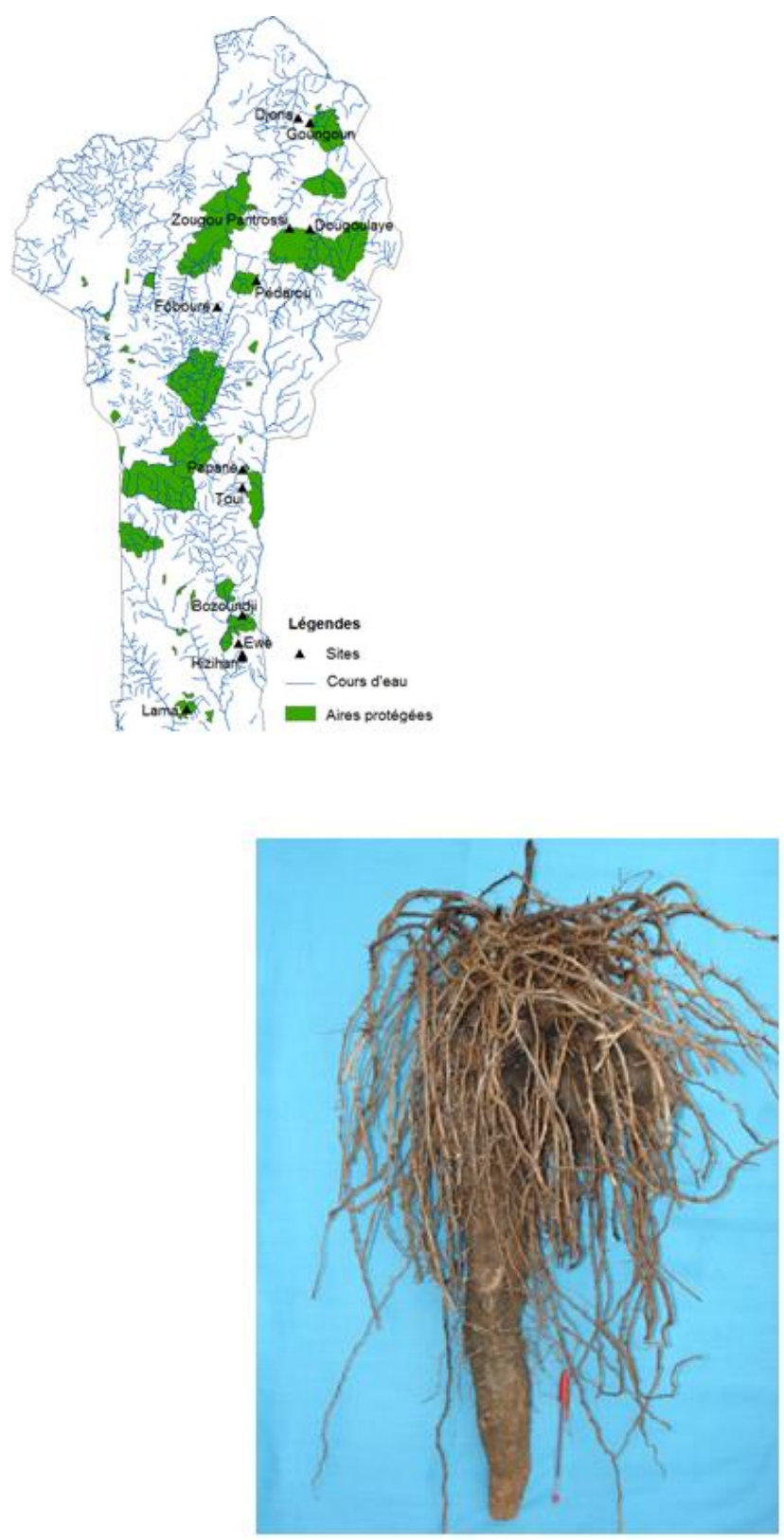

Figure 2-a : Tuber of Non -domesticable Dioscorea praehensilis

\section{Methods}

\subsection{Morphological variability}

The morphological characterization was made using the International Bioversity (ex IPGRI) descriptors (IPGRI/IITA, 1997) already used to characterize a collection of $D$. cayenensis- $D$. rotundata from Ivory Coast (Hamon, 1990), Benin (Dansi et al., 1997) and a collection of D. alata in Vanouatou (Malapa, 2005). It focused on the stem, leaves, tubers and fruits. In total, 34 descriptors have been used. Frequencies of these descriptors within each domesticable or non domesticable group of $D$. abyssinica and $D$.
Figure 1: Collection sites of wild yams

\section{Sampling}

In total, 140 tubers belonging to $D$. praehensilis and D. abyssinica were sampled including 53 domesticable $D$. abyssinica, 38 non domesticable $D$. abysinica, 19 domesticable $D$. praehensilis and 18 non domesticable D. praehensilis (Fig 2). A complementary survey was carried out in the forest of Goungoun and in the hunting zone of Djona, where yam was never produced. So yams collected there were supposed to be real $D$. abyssinica wild types. Eleven accessions were sampled. These, as well as one D. togoensis individual were used as control. Prospection in this area was made without the participation of yam domestication practicing.

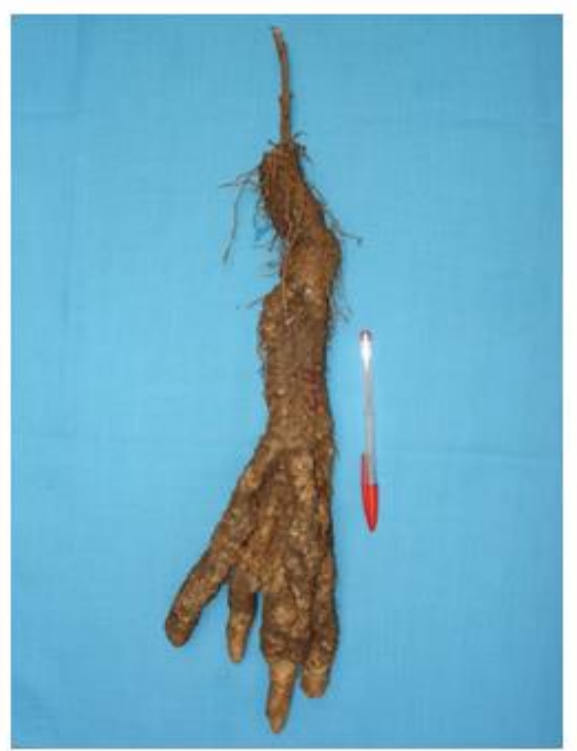

Figure 2-b: Tuber of Domesticable Dioscorea praehensilis

praehensilis were calculated: frequency $=$ (number of individuals from the group with the modality/strength of the species) $x 100$. Following this calculation, the most discriminating descriptors were selected for analysis. A total of 20 descriptors with 61 terms were selected. The characters such as the direction of the winding and the pubescence of the stem, the color of the upper and lower leaf ribs, the color of the leaf margins, the pubescence of the lower and upper surface of leaves, the pubescence and spinescence of the petiole and the smell of the flowers are classified as monomorphic characters, and those relative to the presence of bloom on upper and lower sides of leaves, the sex of the plant, the type of inflorescence 
and fruit are little polymorphic characters. Monomorphic characters are not used for the analysis in the same way as the little polymorphic characters.

Morphological data were saved in Excel format and imported into NTSYS. The methodology used is to compare the affinity groups obtained by the factorial analysis (AFTD). It described a relationship of similarity between individuals which the metric was based on the calculation of an arithmetic average distance. This method aimed to organize diversity without any prioritization on the existing genetic structure by treating all evaluated characters equal. The index of dissimilarity used was that of Dice that is better suited to the analysis of unweighted qualitative characters whose terms are encoded in the presence (1) / absence (0) on a simple disjunctive table.

\subsection{Genetic diversity study using microsatellite markers}

\subsubsection{DNA Extraction}

The extraction has been performed according to Tostain et al 2007 with a slight modification. For each of the 140 samples, approximately $500 \mathrm{mg}$ of fresh leaves were collected and milled in liquid nitrogen. MATAB extraction buffer preheated at $74^{\circ} \mathrm{C}$ was added to the homogenate. The mixture thus obtained was maintained at that temperature in an oven for 20 minutes. The DNA released into the buffer was precipitated with isopropanol and resumed in $\mathrm{NaCl}$.

On the basis of the DNA concentration, dilution with pure water was performed to obtain a concentration of $10 \mathrm{ng} / \mu \mathrm{l}$ required for microsatellite markers technique.

\subsubsection{Microsatellite technique}

Microsatellite markers are best suitable for this analysis. In addition to their distribution throughout the genome, the interest of these markers is their extremely high polymorphism. These are codominant markers (Powell et al., 1996; Santoni et al. 2000), and accordingly, the better indicated for genetic diversity analysis.

The 10 primers pairs used (Table 1) were identified on Yam. They were labeled with the $\gamma 33 \mathrm{P}$ in the presence of polynucleotide kinase T4NPK and kinase buffer. PCR was performed in $25 \mu \mathrm{L}$ reactions in an automated thermal cycler and the program included the following cycles: initial denaturation at $94^{\circ} \mathrm{C}$ for $5 \mathrm{~min} ; 30$ cycles of denaturation at $94^{\circ} \mathrm{C}$ for $30 \mathrm{~s}$, annealing temperature for $30 \mathrm{~s}$ and extension at $72^{\circ} \mathrm{C}$ for $1 \mathrm{~min}$; and a final extension step at $72^{\circ} \mathrm{C}$ for 10 min. PCR amplification was followed by electrophoresis of PCR products on a polyacrylamide gel $5 \%$. The migration was done in TBE buffer for 1 h $30 \mathrm{~min}$ approximately according to the primer. The gel was dried under vacuum at $80^{\circ} \mathrm{C}$ for 20 to 30 minutes, placed in a cassette in contact with self radiographic film from 2 to 5 days. The profiles were revealed by immersing the films successively in a revelation and fixation solution.

\subsubsection{Data processing}

The films were analyzed under UV light. Data were captured in the form of allelic composition at each locus in an Excel spreadsheet for analysis. The dendrogram resulting from polymorphism length was plotted using the Neighbor Joining (Saitou, 1987) based on the index of dissimilarity from the software DARWIN 4.0 (Perrier et al 2003) that use the method of, the Neighbor Joining (Saitou, 1987), based on an index of dissimilarity taking into account common attendance.

\section{RESULTS}

\section{Survey area}

Across the geographical areas and ethnic groups surveyed, different morphotypes of domesticable and non domesticable of both species were identified and the number varies from one region to another. In the northern part of the country, four domesticable morphotypes and one non domesticable morphotype of $D$. abyssinica were found (see Table 1 for each morphotype traits). 
Table 1: Characteristics of different morphotypes collected from the north

\begin{tabular}{|c|c|c|c|c|}
\hline Vernacular names & Status & Tuber' aspect & Stem' aspect & root \\
\hline Digui Teingni & Domesticable & $\begin{array}{lrr}\begin{array}{l}\text { Located } \\
\text { surface } \\
\text { surface }\end{array} & \text { near the } \\
\text { soil' }\end{array}$ & Slightly spiny & $\begin{array}{l}\text { Many roots on the } \\
\text { tuber }\end{array}$ \\
\hline Digui Waaha & Domesticable & $\begin{array}{l}\text { Very long with } \\
\text { bearin calluses; } \\
\text { located } \\
\text { approximately } \\
40 \mathrm{~cm} \text { from the soil' } \\
\text { surface }\end{array}$ & Weakly thorny & Absence of roots \\
\hline Digou Wongourou & Domesticable & Non-deep tuber & $\begin{array}{l}\text { Thorny stem at the } \\
\text { base; presence of } \\
\text { cataphylls facing } \\
\text { downwards }\end{array}$ & $\begin{array}{l}\text { Strong roots } \text { on its } \\
\text { head and small } \\
\text { roots on its } \\
\text { posterior part }\end{array}$ \\
\hline Worou Dogorogou & Domesticable & $\begin{array}{l}\text { Long tuber located } \\
\text { near soil' surface; }\end{array}$ & $\begin{array}{l}\text { Spiny at the base; } \\
\text { have cataphylls } \\
\text { facing upwards }\end{array}$ & $\begin{array}{l}\text { Strong roots } \text { on its } \\
\text { head and small } \\
\text { roots on its } \\
\text { posterior part }\end{array}$ \\
\hline Dika Yamberekou & Non domesticable & Slender, & $\begin{array}{lr}\text { Very weakly with } \\
\text { very } & \text { small } \\
\text { cataphylls } & \end{array}$ & rarely \\
\hline
\end{tabular}

In the Center, the most domesticated species is Dioscorea abyssinica. According to farmers, there is only one domesticable morphotype of $D$. abyssinica. They identified non-domesticable to $D$. dumetorum, $D$. togoensis, D. hirtiflora, D. smilacifolia, $D$. bulbifera and $D$. preussi. These farmers therefore were not able to recognize non-domesticable $D$. abyssinica. They call all wild yams "ItchouIgbo". Contrary to the farmers located in the centre, farmers from South, distinguished two groups within $D$. praehensilis; the non domesticable morphotype) and the domesticable morphotype (Fig. 2).

The domesticable morphotype of $D$. praehensilis across Nago and Fon ethnic groups' areas is "Dohoun Assi". It presented some characteristics related to an average diameter rods (about $0.5 \mathrm{~cm}$ ) which bear spines of variable length and average cataphylls. Its tuber flesh white and was protected by a small crown of thorns. The spines are inclined to the crown axis. The non-domesticable morphotype was named "Dohoun Assou", and presented a large-diameter (approx. $1 \mathrm{~cm}$ ) and strongly spiny stem. It has very long thorns generally curved, large cataphylls and sheathing. Its tuber flesh red and rich in fibers was protected by a crown with enough thorns that is flush with the soil' surface. The spines were perpendicular to the crown axis.

The obtained results showed that there is a geographical structuring of both $D$. abyssinica and $D$. praehensilis species under study. Indeed, $D$. abyssinicais subservient to the degraded mesophilic forests or savannas in the North, while $D$. praehensilis was mainly encountered in dense forest and gallery forests of the South. However, these two species grown in sympatric in the Center.

\section{Morphological variability}

Results from this characterization allowed to determine three types of characters such as monomorphic characters, little polymorphic characters (whose frequency in each of the groups was about $50 \%$ for one any terms) and the polymorphic characters.

The distribution of frequencies of the polymorphic characters evaluated highlights the following morphological distribution. Dioscorea abyssinica and D. praehensilis, were herbaceous twining stem. The number of stems per plant varied from 1 to 6 in the collection with a predominance of one stem per plant. Indeed, $34.11 \%$ of domesticable D. abyssinica, (DabD), $40 \%$ of non-domesticable (DabND); $42.30 \%$ of D. Praehensilis domesticable (DpD) and $50 \%$ of the non-domesticable (DpND) have one stem per plant. Stems were green, brown or purple color, and had dextral rolling. Absent in D. abyssinica, dark brown color characterized $D$. praehensilis including non domesticable according to its frequencies in each of these groups $(3.84 \%$ for $\mathrm{DpD}$ vs. $23.07 \%$ for DpND).

Conversely, only $D$. abyssinica has purple stems. The bloom on the stems seemed characteristic of $D$. abyssinica. Indeed, $65.88 \%$ among which $44.70 \%$ of DabD and $21.18 \%$ of DabND beared bloom on the 
stems against only $15 \%$ of DpD and DpND. The stem was usually thorny. The strong spinescence characterized especially non domesticable $D$. praehensilis (46.15\% vs. $26.92 \%$ for DpD) clearly separating $D$. abyssinica and $\mathrm{DpD}$ by their long spines (19.23\% vs. $0 \%$ for DpD, DabD and DabND). If the length of the spines separates these different groups, their forms and colors, on the contrary, were very little discriminate. The large cataphylls was much more present on the stem of $D$. praehensilis than D. abyssinica.

Based on farmer practice and according to this morphological analysis, domesticable and nondomesticable yams were distinguished by their stems and tubers. Indeed, domesticable D. praehensilis had a medium diameter stem, bearing thorns and medium-sized cataphylls while non-domesticable had a large diameter stems strongly thorny with thorns and very large cataphylls. As for D. abyssinica, domesticable morphotypes had a covered stem of bloom and bringing spines with medium length while non domesticable had stem bearing little bloom with very short spines.

Three groups GI, GII and GIII resulted from the AFTD (Fig. 3) obtained after morphological characterization of the accessions identified as domesticable and non domesticable by farmers.

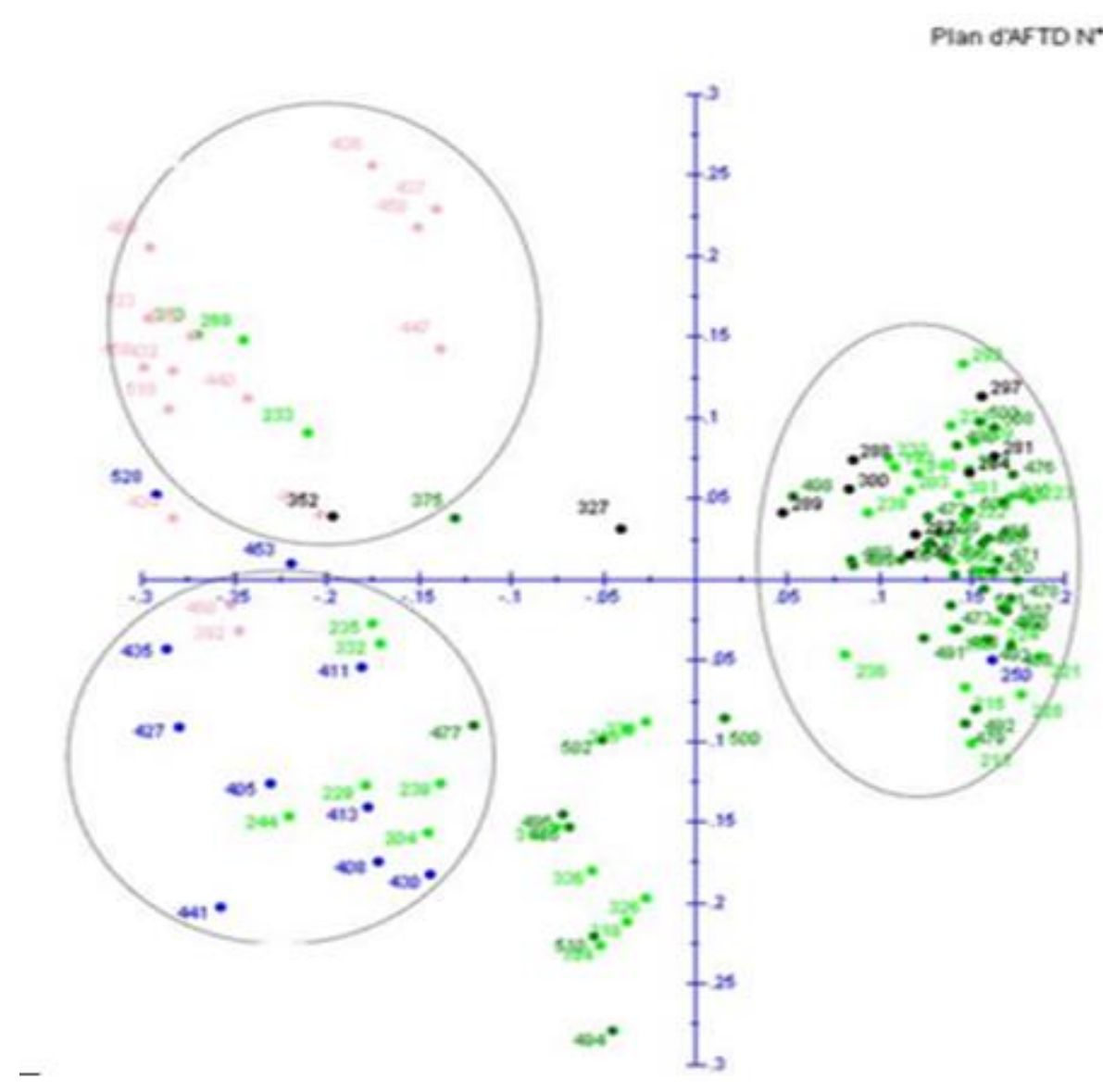

Figure 3: Principal component analysis of accessions

The group GI, gathered mostly accessions of non domesticable (Dohoun Assou) D. praehensilis among which $81 \%$ are represented. It also contained $18 \%$ of domesticable D. praehensilis; and respectively $2 \%$ and $7 \%$ of non domesticable and domesticable of $D$. abyssinica of domesticable D. praehensilis accessions were collected in the forest of Lama in the South and had the predominant characters of $D$. praehensilis as thorny stem and crown of thorns bearing by the tuber. The unique non domesticable $D$. abyssinica was collected in the forest of Toui-Kilibo located in the sympatric area of the center where $D$. abyssinica and D. praehensilis coexisted. It carried a highly thorny stem like $D$. praehensilis. Finally, the $7 \%$ of domesticable $D$. abyssinica were collected in the North in the forest of three rivers located in Zougou Pantrossi and Dougoulaye localities. These accessions had a strongly thorny and robust stem with very long spines which were characteristics of $D$. praehensilis.

The group GII was composed largely of domesticable D. praehensilis ( $81 \%$ of accessions) and a few other 
individuals misfiled. Indeed, it contained $12 \%$ of the non-domesticable D. praehensilis, $15 \%$ of non domesticable D. abyssinica and $30 \%$ of domesticable D. abyssinica.

The GIII group gathered all $D$. abyssinica accessions. There was no non domesticable D. praehensilis belonging to this group. Only one domesticable $D$. praehensilis was found to belong to this group and were gathered at Dougoulaye, the predilection area of D. abyssinica.

Overall, a continuum was observed between the various groups highlighted but the separation of non domesticable $D$. praehensilis seems clearly.

\section{Microsatellite markers polymorphism and diversity level}

By using the ten SSR markers, one hundred and twenty-one alleles have been revealed among the 140 accessions with an average of 12 alleles per locus. The number of alleles per locus varied from 3 to 23 . The lowest and the highest values were obtained respectively for the locus Dab2C12 and Dab2E09. Heterozygosity' rates varied strongly from $10.48 \%$ to $100 \%$ with an average to 61.6 . Table 2 presented a summary of genetic value obtained with SSR markers used.

Table2: Summary of genetic diversity parameters

\begin{tabular}{|c|c|c|c|c|c|c|c|}
\hline \multirow[t]{2}{*}{ Locus } & \multirow{2}{*}{$\begin{array}{l}\text { Number } \\
\text { of allele }\end{array}$} & \multicolumn{5}{|c|}{ Heterozygosity } & \multirow{2}{*}{$\begin{array}{c}\text { Global } \\
\text { heterozygosity } \\
(\%)\end{array}$} \\
\hline & & $\mathrm{Dab}$ & Dabw+ & $\begin{array}{l}\text { DabT } \\
\text { S }\end{array}$ & $\mathrm{Dp}$ & Dpw+ & \\
\hline $2 \mathrm{~F} 10$ & 7 & 9.43 & 5.12 & 9.09 & 10.52 & 16.66 & 10.48 \\
\hline 1F07 & 9 & 45.25 & 71.79 & 63.63 & 15.78 & 16.66 & 50.78 \\
\hline $1 \mathrm{~A} 01$ & 9 & 54.71 & 48.71 & 72.72 & 47.36 & 55.55 & 55.97 \\
\hline 1D08 & 15 & 54.71 & 41.02 & 63.63 & 31.57 & 61.11 & 63.30 \\
\hline $1 \mathrm{G} 12$ & 6 & 28.30 & 5.12 & 18.18 & 5.26 & 11.1 & 20 \\
\hline Dab2C12 & 12 & 94.33 & 100 & 100 & 100 & 100 & 100 \\
\hline Dab2E09 & 23 & 67.92 & 64.10 & 72.72 & 94.73 & 66.66 & 83.19 \\
\hline Dab2D08 & 13 & 75.47 & 61.53 & 100 & 73.68 & 77.77 & 88.97 \\
\hline Dab2C05 & 22 & 73.58 & 51.28 & 72.72 & 84.21 & 44.44 & 69.46 \\
\hline Dab2D11 & 14 & 69.81 & 58.97 & 72.72 & 52.63 & 83.33 & 74.40 \\
\hline
\end{tabular}

Table 3: Different genetics groups revealed by microsatellite markers

\begin{tabular}{lccccc}
\hline & $\mathrm{G}_{1}$ & $\mathrm{G}_{2}$ & $\mathrm{G}_{3}$ & $\mathrm{G}_{4}$ & $\mathrm{G}_{5}$ \\
\hline DabD & $\mathbf{4 2 . 3 0}$ & 1.92 & 13.45 & 9.61 & $\mathbf{3 2 . 6 9}$ \\
DabND & 0 & 2.56 & $\mathbf{7 1 . 7 9}$ & 10.24 & 15.38 \\
DabST & 8.33 & 0 & 0 & 8.33 & $\mathbf{8 3 . 3 3}$ \\
DpD & 0 & $\mathbf{6 3 . 1 5}$ & 10.52 & 15.78 & 10.52 \\
DpND & 5.55 & 0 & 16.66 & $\mathbf{7 2 . 2 1}$ & 5.55 \\
\hline
\end{tabular}

DabD : domesticable D. abyssinica

DabND : Non domesticable $D$. abysinica

DabST : D. abyssinica supposed to be wild typeDpD : domesticable $D$. praehensilis

DpND: Non domesticable D. praehensilis

The first group G1 mainly consisted of $42.30 \%$ of domesticable $D$. abyssinica. This group also contained $8.33 \%$ of true wild type of $D$. abyssinica, and $5.55 \%$ of non domesticable $D$. praehensilis. The accession 349, a non domesticable D. praehensilis, from the forest of three rivers, belonged to this group, but normally classified in its group when using morphological characters. There was no non domesticable $D$. abyssinica and no domesticable $D$. praehensilis belonging to this group. The group G2 was mainly composed of domesticable $D$. praehensilis representing $63.15 \%$ of the total 
population. Only $1.92 \%$ and $2.56 \%$ respectively of domesticable and non domesticable D. abyssinica were present.

The group G3 appeared as the group of nondomesticable $D$. abyssinica accessions whose $71.79 \%$ were represented. It also contained $13.45 \%$ of domesticable $D$. abysinica, $10.52 \%$ of domesticable $D$. praehensilis and $16.66 \%$ of non-domesticable $D$. praehensilis. The alone species $D$. togoensis used as a control belonged to this group. Group 4 was mainly represented by the non domesticable $D$. praehensilis which represented $72.21 \%$ of species. $15.78 \%$ of domesticable D. praehensilis, $10.24 \%$ of non domesticable D. abyssinica, $9.61 \%$ of domesticable $D$. abyssinica and $8.33 \%$ of the true wild types of $D$. abyssinica were also represented in this group. The group G5 was that of the D. abyssinica which was assumed to be the true wild type with a rate of $83.33 \%$. It also contained $32.69 \%$ of domesticable and $15.38 \%$ of non domesticable D. abyssinica.

Analysis showed that domesticable $D$. abyssinica and D. praehensilis were very closed and presented very close genetic distances. Similar observations were made for the non domesticable accessions of both species. On the whole, molecular data were more suitable than morphological ones. However, it presented similar structuring for both domesticable and non domesticable $D$. praehensilis.

The accessions 222, 228, 237, 239, 261, 326 and 352 were domesticable $D$. abyssinica. They were harvested in the North just as non domesticable: 222, 237, 239 (Digui Waaha), 228 (Digou Wongourou) and 261 in the forest of three rivers. The first, Digui Waaha, had very large leaves as the supposed non domesticable $D$. abyssinica while 326-352 accessions were harvested at the centre in the forest of TouiKilibo.

D. praehensilis accessions domesticable of this group were samples numbered 519-526 accessions to the South in the forest of Lama.

409, 440 and 518 accessions represented $D$. praehensilis non domesticable. The first were collected respectively in Ewe forest and gallery forest of Bozoundji in the town of Kétou, area very close to the centre. According to the peasants living in this area, simply bike 1 hour to get to Paouignan and especially to Glazoué which houses the largest market of marketing of yams of the Benin centre. Thus, there was an intense human migratory flows between the region of Ketou and the centre of Benin. The G4 group was that of $D$. praehensilis non domesticable because it contained $72.21 \%$ of individuals. It also contained $15.78 \%$ domesticable D. praehensilis, $10.24 \%$ non domesticable $D$. abyssinica, $9.61 \%$ domesticable D. abyssinica and $8.33 \%$ of the true wild types of $D$. abyssinica.
Domesticable D. praehensilis accessions were 427, 430 and 528. The first were sampled in the same gallery forest of Bozoundji as non-domesticable while the last comes from the forest of Lama. Morphologically, the 528 accession was also grouped with $D$. praehensilis non domesticable. In the last case, molecular and morphological data were consistent.

D. abyssinica accessions domesticable of this group were: 214, 230 and 267 harvested in the forest of three rivers, 335 and 381 sampled in the forest of Toui-Kilibo. And after the morphological analysis, none of these $D$. abyssinica occured with nondomesticable D.praehensilis.

Those of $D$. abysinica non domesticable of this group were 472, 477, 488 and 489 harvested in the forest of Ouenou/Benou to the North. Morphological data classify accession 477 in D. praehensilis domesticable group and 472, 488 and 489 individuals in that of D. abyssinica.

\section{DISCUSSION}

\section{Sampling and morphological variability}

From the results obtained during surveys, it appears clearly that wild yam domestication is not widespread because very hard to be achieved by farmers. They need to go very far in the forest to gather wild material to be domesticated, which have, as the case of $D$. praehensilis, a crown of thorns and deep tuber. The low level of domestication across the bariba ethnic group in particular, was also related to the dishonorable aspect of this practice.

Surveys revealed the existence of four different morphotypes of domesticable $D$. abyssinica. This result was in accordance with those reported by Vernier et al. (2003) but contrary to those reported by Baco who previously identified three morphotypes (Baco, 2000) in the same cultural area. This variation in the number of domesticable morphotypes reflects the lack of control of the phenomenon of the domestication by a large number of farmers (Baco, 2000; Vernier et al., 2003). Likewise, the domestication could be considered as a subjective phenomenon because what is domesticable for some farmers is not always for others.

This lack of objectivity was shown through one of the farmers' criteria for the identification of $D$. praehensilis domesticable and non-domesticable which is the orientation of thorns of the crown. This criterion is not always reliable because in a very hard soil, a non-domesticable species can have twisted spines, supposed characteristic for domesticable. 
The alone non domesticable morphotype of $D$. abyssinica namely Dika Yamberekou identified during this work has also been identified previously by Dumont, Vernier and Baco. For the former, this morphotype is D. togoensis unlike Baco (2000) estimated that some accessions in this group belong to $D$. togoensis and others to $D$. abyssinica. This hypothesis of Baco seems validate our morphological analyses.

The morphological criteria used to describe the leaves and stems are mostly in agreement with those of Dumont et al., 2002 and Hamon et al. (1995). The present work provides, however, a little bit details on certain characters. According to Dumont et al. (2000), the stem of domesticable D. praehensilis and that of all $D$. abyssinica is clear while those of non domesticable $D$. praehensilis is dark. Our results show that the clear stem is rather green or purplish and dark stem is dark brown. They also revealed that the stem spinescence is very strong in non domesticable $D$. praehensilis and medium in the domesticable. This observation was not mentioned by Dumont et al. (2002). Addition discriminatory morphological criteria were used for the morphological characterization. These include the shape and length of thorns of stem, the aspect of stem and its bloom coverage, and the texture of leaves.

Factorial analysis does not show a strong structuration of morphological variability (Fig. 2). Therefore, there is no clear limit between $D$. abyssinica and D. praehensilis. However, there are, in general, significant differences between $D$. abyssinica and D. praehensilis tubers that would more clearly separate these two species. Accessions of $D$. abyssinica misclassified could be $D$. praehensilis adapted to the savannah ecosystem. Their phenotypic plasticity would be expressed in savannah environment making them morphologically close to D. abyssinica. As suggested by Dumont (1997), D. abyssinica is a form of yam provided by the adaptive transformation of the $D$. praehensilis species in savanna ecosystem. There are still a few characters that separate them such as the texture of the leaves, their form, stem spinescence, and size of cataphylls.

However, the AFTD highlights a separation between the domesticable and non-domesticable within $D$. praehensilis. The discriminating characters are the stem' diameter, color and spinescence. This clear separation between domesticable and nondomesticable $D$. praehensilis demonstrates the reliability of the markers selected for this species. These results are consistent with the farmers' perception who easily distinguished these two groups. This is justified by the production in large amount of yam "Gban", product of domestication of
D. praehensilis in gardens of southern Benin (Tostain et al, 2002).

On the other hand, these markers were unable to separate domesticable and non-domesticable $D$. abyssinica. In situ observations, showed non domesticable $D$. abyssinica having long and broad leaves with medium diameter tuber size and which look much more like those of $D$. abyssinica. Only one accession produces bulbils, a characteristic that bring it closer to D. togoensis. This indicates that, all of non domesticable $D$. abyssinica are undoubtedly not D. togoensis.

D. abyssinica' accessions form an homogenous group with, however, a few individuals in the compartment of domesticable and non-domesticable $D$. praehensilis. Indeed, accessions 326, 330 and 375 were collected in the degraded mesophilic forest of Toui-Kilibo where D. abyssinica and D. praehensilis live sympatric. It is therefore not surprising that these individuals belonging to $D$. abyssinica group together with $D$. praehensilis due to probable gene flow between these two species. These accessions could be interspecific hybrids as reported by Zoundjihekpon et al. (1994). Gene flow might explain the closeness among several accessions of $D$. praehensilis and $D$. abyssinica.

The continuum observed between different groups had also been highlighted by Hamon (1990), Dang et al. (1998) on D. rotundata and Malapa (2005) on the case of $D$. alata. This continuum observed during these morphological analyses leads to the question of the separation of these two species. It also reflects the difficulties encountered by farmers in the choice of the domesticable genotypes of $D$. abyssinica and result in the failures of the process of domestication (Tostain et al. 2003).

\section{Genetic diversity study using microsatellite markers}

By using nuclear microsatellites markers, distinct groups of $D$. abyssinica and $D$. praehensilis were obtained. Similar results were reported by Scarcelli et al. (2006), using dominant markers such as AFLP markers to characterize collections of cultivated, predomesticated and wild yams of $D$. abyssinica and $D$. praehensilis from Benin. Moreover, Mignouna et al. (2003), when analyzed Nigeria' yam collection reported similar results.

But beyond the simple separation of $D$. abyssinica and $D$. praehensilis into two genetically distinct groups, nuclear microsatellites used for this work revealed a fine genetic structuring of these two wild species. Indeed, a clear separation of each of the two species $D$. abyssinica and $D$. praehensilis in domesticable and non-domesticable was obtained through a belonging to distinct genetic groups. This 
observation supports the hypothesis of the existence of a strong genetic component in the ability to domesticate yams. These molecular data are in perfect accordance with the knowledge of farmers separating $D$. abyssinica and D. praehensilis into domesticable and non domesticable groups on the basis of morphological characters. Therefore, farmers' endogenous knowledges need to be documented and exploited.

However, on the basis of molecular markers, some individuals were found in groups different from those obtained using morphological characters. These results show that the morphological characters are far less suitable for the identification of varieties. $D$. abyssinica form an heterogeneous group (G5) domesticable and non-domesticable accessions. An hypothesis is that majority of $D$. abyssinica supposed to be domesticable by farmers who group it in G1, could be elders cultivated or escaped from cultivation. They were sampled in forests classified "protected zones" during the years 1940s and 1950s. This hypothesis is in agreement with Dumont and Vernier (2000) who consider that, after a long fallow, cultivated accessions can return to wild morphotypes. Thus, domesticable $D$. abyssinica could be divided into two groups: escaped crop and real wild type (G5). This hypothesis was previously evoked by Chaïr et al. (2005) from research conducted on genetic diversity of $D$. abyssinica and $D$. praehensilis.

Despite the absence of morphological characters which would have assimilated non domesticable $D$. abyssinica to D. togoensis as pointed out previous works (Vernier et al. 2003), they were genetically closer to the latter species whose control used is in this study clustered in the same group. Thus, the real genetic nature of non domesticable $D$. abysinica deserves to be studied more thoroughly.

\section{CONCLUSION:}

This study showed that wild yam domestication is not widespread because very hard to be achieved by farmers and also considered as dishonorable practice across the bariba ethnic group, recognized as a bigger yam producers. Only few domestication practicing have good skills on this practice. Our results showed that their morphological criteria of choice of wild material to be domesticated have a genetic basis. Indeed, a clear separation of each of the two wild species Dioscorea abyssinica and Dioscorea praehensilis in domesticable and non-domesticable was detected. Thus, molecular data were in perfect accordance with the knowledge of farmers separating D. abyssinica and D. praehensilis into domesticable and non domesticable groups on the basis of morphological characters. Therefore, farmers' endogenous knowledge needs to be documented and exploited.

CONFLICT OF INTEREST: No conflict of interest

ACKNOWLEDGMENTS: We would like to thank J. M. AWADIDA, English translator, who has read the final manuscript.

\section{REFERENCES}

1. Adejumo B. A., Okundare R. O., Afolayan O. I., Balogoun S. A. 2013: Quality attributes of yam flour (Elubo) as affected by blanching water temperature and soaking time. Intl. J. Engr. Sci. (IJES), 2(1): 216-221.

2. Adoukonou S. H. (2001) : Gestion paysanne de la diversité génétique des ignames du complexe Dioscorea cayenensisDioscorea rotundata au centre du Bénin. Mémoire de DEA Faculté des Sciences, Université de Lomé (Togo), 56p.

3. Akoroda M. O. (1983): Variation, heritability and geneticadvance of eight characters in white yam. Theor. Appl. Genet., 66: 51-54

4. Baco M.N. (2000) : La "domestication" des ignames sauvages dans la Sous-Préfecture de Sinendé: savoirs locaux et pratiques endogènes d'amélioration génétique des $D$. abyssinica. Mém. Ingénieur agronome, Université d'AbomeyCalavi, Bénin, 170 p.

5. Baco M.N. (2003) : Etude de la faisabilité d'une gestion et d'une conservation in situ de l'agrobiodiversité : le modèle igname dans le nord Bénin. DEA Aménagement, Développement, Environnement, Université d'Orléans, France, $106 \mathrm{p}$.

6. Chaïr H., Perrier X., Agbangla C., Marchand J.L., Dainou O.and Noyer J.L. (2005): Use of cpSSRs for the characterisation of yam phylogeny in Benin. Genome. 48:674-684.

7. Dansi A., Zoundjihékpon J., Mignouna H. D. et Quin M. (1997) : Collecte des ignames cultivées du complexe Dioscorea cayenensis-rotundata au Bénin. Plant Genetic Resources Newsletter, 112: 81-85

8. Dansi A., Zoundjihékpon J., Mignouna H.D. et Quin M. (1998) : Approche participative pour une conservation durable des ressources génétiques des ignames du Bénin. IPGRI Newsl. For Sub-Saharan, 10: 8-9

9. Dansi A., Mignouna H.D., Zoundjihékpon J., Sangare A., Assiedu R. and Quin M. (1999): Morphological diversity, cultivar groups and possible descent in the cultivated yams (Dioscorea cayenensis-D. rotundata complex) of Benin Republic. Genet. Resour. Crop Evol., 46: 371-388

10. Degras L. (1986) : L'igname, plante à tubercule tropicale. Ed.Maisonneuve et Larose et ACCT., Paris, 409 p.

11. Doukouré S. (2000) : Amélioration de la production de l'igname, à bouturage in vitro, chez les cultivars florido et brazo fuens. Thèse Doctorat Ingénieur, UFR Bioscience, Université de Cocody Côte, d'Ivoire, 143 p.

12. Dumont et Vernier (1997) : La domestication des ignames (D. cayenensis- rotundata) chez la population Bariba du Bénin. In colloque Gestion des ressources génétiques des plantes en Afrique de 1'Ouest, Bamako, Mali, 24-28 Février 1997, 13 p.

13. Dumont R. (1997) : La production d'ignames dans un village bariba du Bénin septentrional. Les Cahiers de la Recherche Développement, 43 : 35-51.

14. Dumont R. (1998) : Domestication des ignames en Afrique. In J. Berthaud, N. Bricas, J.L. Marchand, CIRAD/INRA/ORSTOM/CORAF, 3-6 juin 1997, Montpellier (France), pp. : 71-76.

15. Dumont R. and Vernier P. (2000): Domestication of yams (Dioscorea cayenensis-rotundata) within the Bariba ethnic group in Benin. Outlook on Agriculture, 29 (2) : 137-142.

16. Dumont R., Dansi A., Vernier P., Zoundjihékpon J : 2002 (sous presse) Les ignames D. rotundata Poir, leurs parents 
sauvages présumés et les méthodes de domestication observées en Afrique de l'Ouest, 55p.

17. Emberger L. (1960) : Traité de botanique. Masson éd., 1540 p.

18. FAO (2014) FAOSTAT Database. Food and Agriculture Organization, Roma, Italy. www.fao.org

19. Gnamkoulamba A. (2001) : Problématique de la domestication d'une espèce d'igname sauvage : Bayere (Dioscorea praehensilis) à Agbokopé (Préfecture de Wawa) au Togo. Mem. DESS, FA/CRESA, Niamey, Niger, 72p.

20. Hamon P. (1987) : Structure, origine génétique des ignames cultivées du complexe Dioscorea cayenensis-rotundata et domestication des ignames en Afrique de l'ouest. Thèse de Doctorat, Université Paris XI, Centre d'Orsay, 223 p.

21. Hamon S. (1990): The classification of cultivated yams (D. cayenensis-D. rotundata complex) of West Africa. Euphytica, 47: 179-187.

22. Hamon P., R. Dumont, J. Zoundjihékpon, B. Tio-Touré, S. Hamon (1995) : Les ignames sauvages d'Afrique de l'ouest. ORSTOM éditions, Collection Didactique, Paris, pp. 84.

23. IPGRI (1997) : Descripteurs de l'igname (Dioscorea spp). IPGRI eds., pp.65.

24. Malapa R, Arnau G, Noyer JL, Lebot V. 2005. Genetic diversity of the greater yam (Dioscorea alata L.) and relatedness to Dioscorea nummularia Lam. and Dioscorea transversa $\mathrm{Br}$. as revealed with AFLP markers. Genetic Resources and Crop Evolution 52 :919-929.

25. Malaurie B., Trouslot M.F. et Berthaud J. (1997) : Conservation et échanges de germoplasme chez les ignames (Dioscorea spp.). In l'igname, plante séculaire et culture d'avenir. Actes du séminaire international, CIRAD/INRA/ORSTOM/CORAF, 3-6 juin 1997, Montpellier, pp. 135-161.

26. Martin F.W. and Rhodes A.M. (1977): Intra-specific classification of Dioscorea alata. Trop. Agr., 54: 1-13.

27. Megh RajBhandari, Takanori Kasai, Jun Kawabata, 2003. Nutritional evaluation of wild yam (Dioscorea spp.) tubers of Nepal. Food chemistry, Volume 82, Issue 4, September 2003, Pages 619-623

28. Mignouna H. D. and Dansi A. (2003): Yam (Dioscorea ssp.) domestication by the Nago and Fon ethnic groups in Benin. Genetic Resources and Crop Evolution 50: 519-528.

29. Mignouna H. D., Abang M. M., Wanyera N. W., Chikaleke V. A., Asiedu R; and Thottappilly G., 2003. PCR markerbased analysis of wild and cultivated yams (Dioscorea spp.) in Nigeria: genetic relationships and implications for ex situ conservation. Genetic Resources and Crop Evolution : 1-9.

30. Okry K.F. (2000) : L'igname dans le système de production agricole de Bantè et la domestication de quelques-unes de ses formes sauvages: savoirs locaux et pratiques endogènes de culture et d'amélioration génétique. Mém. Ingénieur Agronome, Université Nationale du Bénin, pp.119.

31. Orkwor G. C., Asiedu R. and Ekanayake, (eds). (1998): Food Yams. Advances in Research. IITA and NRCRI, Nigeria, 249 p.

32. Perrier X., Flori A. and Bonnot F. (2003): Methods of data analysis. In Genetic Diversity of Cultivated Tropical Plants. In P. Hamon, M. Seguin, X. Perrier and J.C. Glasszmann, CIRAD, Montpellier, France, pp. 43-76.

33. Perrot C. H. 1997 : L'igname dans les cérémonies politicoreligieuses de l'aire culturelle akan. In l'igname, plante séculaire et culture d'avenir. Actes du séminaire international, CIRAD/INRA/ORSTOM/CORAF, 3-6 juin 1997, Montpellier, pp. 47-50

34. Powell W., Morgante M., Andre C., Hanafey M., Vogel J., Tingey S. and Rafalski A. (1996): The comparision of RFLP,
RAPD, AFLP and SSR (microsatellite) markers for germplasm analysis. Molecular Breeding, 2: 225-238.

35. Ramser J., Weising K., Lopez-Peralta C., Terhalle W., Terauchi R. and Kahl G. (1997) : Molecular marker based taxonomy and phylogenetic of Guinea yam (Dioscorea rotundata-D. cayenensis). Genome, 40: 903-915.

36. Sadik S. Okéréké O.U. (1975): Flowering, pollen grain germination, fruiting, seed germination and seedling development of white yam, Dioscorea rotundata. Annals of Botany, 39: 597-604.

37. Saitou N. and Nei M. (1987): The neighbor-joining method: a new method for reconstructing phylogenetic trees. Mol. Biol. Evol., 4 : 406-425.

38. Santoni S., Faivre-Rampant P., Prado E. et Prat D. (2000) : Marqueurs moléculaires pour l'analyse des ressources génétiques et l'amélioration des plantes. Cahiers Agricultures, 9 : 311-327.

39. Scarcelli N., Tostain S., Mariac C., Agbangla C., Daïnou O., Berthaud J. and Pham J. L., 2006. Genetic nature of yams (Dioscorea sp.) domesticated by farmers in Benin (West Africa). Genetic Resources and Crop Evolution 53:121-130. Doi: 10.1007/s10722-004-1950-5.

40. Terauchi R., Chikaleke V. A., Thottappilly G. \& Hahn S. K. (1992): Origin and phylogeny of Guinea yams as revealed by RFLP analysis of chloroplast DNA and nuclear ribosomal DNA. Theor Appl Genet 83: 743-751.

41. Tostain S., C. Agbangla, et O. Daïnou (2002) : Diversité AFLP des ignames sauvages Dioscorea abyssinica et Dioscorea praehensilis. Annales des Sciences Agronomiques du Bénin, 3 (2): 1-20.

42. Tostain S., Houémassou B. J., Agbo V., Gbéhi C., Agbangla C. et Daïnou O. (2002) : Diversité variétale et domestication des ignames chez les Fon du Bénin. Annales des Sciences Agronomiques du Bénin, 3 (2): 74-93.

43. Tostain S., Allomasso T. et Sokpon N. (2003) : Conservation de l'igname sauvage Dioscorea praehensilis dans les forêts sacrées du département de l'Atlantique (Sud du Bénin) et dans les jardins de cases. Annales des Sciences Agronomiques du Bénin, 4 (1) Spécial colloque, 87p.

44. Tostain S., Agbangla C, Scarcelli N, Mariac C, Daïnou O, Berthaud J, and Pham JL. 2007. Genetic diversity analysis of yam cultivars (Dioscorea rotundata Poir.) in Benin using simple sequence repeat (SSR) markers. Plant Genetic Resources Volume 5, Issue 2 pp. 71-81

45. Touré B. et Ahoussou N. (1982) : Etude de comportement en collection des ignames (Dioscorea spp.) dans deux régions écologiques différentes de la Côte d' Ivoire. In Miège et Lyonga : 23-30.

46. Vernier P., N'kpenu K.E. et Orkwor G.C. (1998) : Analyse comparée de la production d'igname pour la transformation en cossette dans trois pays (Bénin, Nigéria, Togo) : un exemple de sédentarisation de la culture de l'igname. Communication présentée au 7è séminaire triénal de la Société Internationale pour les Plantes à Racines et Tubercules Tropicales-Branche Afrique, Cotonou, Bénin, pp. 11-17.

47. Vernier P., Orkwor G.C. and Dossou A.R. (2003): Studies on yam domestication and farmers' practices in Benin and Nigeria. Outlook on Agriculture 32 (1), pp35-41.

48. Zoundjihékpon J. (1993) : Biologie de la reproduction et génétique des ignames cultivées de l'Afrique de l'ouest, Dioscorea cayenensis-rotundata Thèse de Doctorat, Université Nationale de Côte d'Ivoire, 306 p.

49. Zoundjihékpon J., Hamon S., Tio-Touré B. and Hamon P. (1994) : First controlled progenies checked by isozymic markers in cultivated yams, Dioscorea cayenensis-rotundata. Theor. Appl. Genet., 88: 1011-1016. 